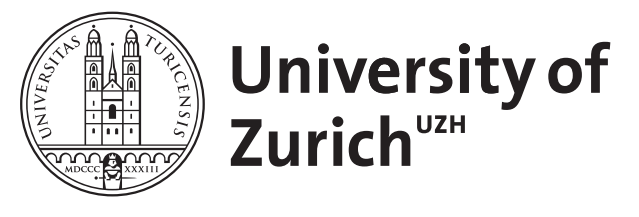

\title{
Posing Questions without Asking
}

\author{
Nowak, Bartholomäus
}

\begin{abstract}
The paper deals with the specific use of rhetorical questions in a particular, national type of parliamentary discourse. After a discussion about rhetorical questions in general, the specifics of the Polish parliamentary discourse are described. The data comes from a part of a parliamentary debate on an emergency topic. This mostly conflictual subgenre is named "issue specific question time". Based on numerous samples, this analysis reveals three main characteristics within the parliamentary use of rhetorical questions in the Sejm: firstly, the Members of Parliament mostly waive self-answering to rhetorical questions; secondly they treat rhetorical questions as an appropriate tool to formulate statements with question syntax. Both findings are based on the specific parliamentary turn taking rules, viz the right to speak is institutionally linked with the requirement to pose at least one question. The third major characteristic is that rhetorical questions were posed in sequences with other standard or non-standard questions. Thus, the clarity of the unspoken answers in the hearer's minds can often be conveyed to the other non-rhetorical questions in the sequence.
\end{abstract}

DOI: https://doi.org/10.1515/slaw-2016-0004

Posted at the Zurich Open Repository and Archive, University of Zurich ZORA URL: https://doi.org/10.5167/uzh-171935

Journal Article

Published Version

Originally published at:

Nowak, Bartholomäus (2016). Posing Questions without Asking. Zeitschrift für Slawistik, 61(1):57-73.

DOI: https://doi.org/10.1515/slaw-2016-0004 


\title{
Bartholomäus Nowak* Posing Questions without Asking
}

\section{The Use of Rhetorical Questions in the Polish Parliamentary Discourse}

DOI 10.1515/slaw-2016-0004

\begin{abstract}
Summary: The paper deals with the specific use of rhetorical questions in a particular, national type of parliamentary discourse. After a discussion about rhetorical questions in general, the specifics of the Polish parliamentary discourse are described. The data comes from a part of a parliamentary debate on an emergency topic. This mostly conflictual subgenre is named "issue specific question time”. Based on numerous samples, this analysis reveals three main characteristics within the parliamentary use of rhetorical questions in the Sejm: firstly, the Members of Parliament mostly waive self-answering to rhetorical questions; secondly they treat rhetorical questions as an appropriate tool to formulate statements with question syntax. Both findings are based on the specific parliamentary turn taking rules, viz the right to speak is institutionally linked with the requirement to pose at least one question. The third major characteristic is that rhetorical questions were posed in sequences with other standard or non-standard questions. Thus, the clarity of the unspoken answers in the hearer's minds can often be conveyed to the other non-rhetorical questions in the sequence.
\end{abstract}

Keywords: Rhetorical question, Political discourse, Parliamentary discourse, Turn taking, The Polish Sejm

\section{Introduction}

The literature about rhetorical questions confronts multiple issues: what a rhetorical question is; why an addressee perceives an utterance in interrogative form as a rhetorical question; and what functions a rhetorical questions performs or illocutionary forces it exerts. This paper will focus on the functional aspect of rhetorical questions, not on their synthetic description. Schmidt-Radefeldt (1977) divides functions of rhetorical questions into two categories. One is, broadly

*Corresponding author: Bartholomäus Nowak, University of Zurich, Plattenstrasse 43, 8032 Zürich, Switzerland, E-Mail: bartholomaeus.nowak@uzh.ch 
speaking, modal. A speaker can use a rhetorical question to highlight certitude or incertitude, to evaluate content, or to express a propositional attitude (such as emphasis, indignation or reproach). Otherwise the speaker can vary the degree of his or her own commitment to the proposition expressed in the utterance or to the utterance itself. These functions are not mutually exclusive. Portraying rhetorical questions as “a type [of] indirect speech act”, Frank (1990: 723-4) also spots "multiple purposes" that such questions perform, while emphasizing that their functions exclude requests for information. In her analysis, their main function is mitigation of face-threatening acts. Because interrogative form casts doubt on the speaker's certitude or commitment, addressees can tolerate stronger statements than they would accept if posed as assertions (Frank 1990: 725). The comprehensive analysis of rhetorical questions by Ilie (1994) further develops the theme of "multifunctionality" (Ilie 1994: 59). According to her, rhetorical questions function both as statements and as questions. Interrogative form enables speakers to avoid full responsibility for the utterance and can function as challenge, that is casting doubts on the validity claims of the addressed person (Lachenicht 1980: 668-675). A feature peculiar to rhetorical questions is their capacity to act as valid answers to previous questions (authentic or rhetorical) posed by an interlocutor and even to reveal a positive commitment by the speaker to his or her answer (Ilie 1994: 217). ${ }^{1}$ Even from this brief, loose and fragmentary enumeration of functions ascribed by literature to rhetorical questions, still a certain characterization of rhetorical questions emerges. Instead of providing evidence for or against any precise definition of rhetorical question, I will refer to Ilie (1994), who offers an extensive summary of the debates over ubiquitous definitions. Repetition of all her arguments is superfluous, but her own attempt to offer a comprehensive definition merits a simplified presentation. For Ilie (1994: 128) a rhetorical question uses interrogative form to present a challenging statement that expresses the speaker's commitment to the implicated answer with the aim of obtaining recognition in the addressee's mind.

In sum, three issues are particularly relevant for the analysis of rhetorical questions. First is the capacity of rhetorical questions to act as answers to previous questions, which relates to the fundamental puzzle posed by the discrepancy between question form and statement. Second is the "multifunctionality” (Ilie 1994) or "multiple purposes” (Frank 1990) cited previously. Most of these

\footnotetext{
1 The function of rhetorical questions as appropriate answers to questions was stressed in detail by Ilie for the courtroom discourse (Ilie 1995) and in TV talk shows (Ilie 1999). In keeping with the rhetorical question as answer function, Schaffer (2005) itemized it by formulating the "rhetorical question-as-retort" concept, to focus on rhetorical questions as "quick, often witty, sometimes sharp-edged verbal repl[ies]" (Schaffer 2005: 435).
} 
functions are neither exclusive nor peculiar to rhetorical questions, and any given rhetorical question may perform several of the possible functions. What functions a given rhetorical question performs depends on various contextual considerations, such as genre of the text in which the question appears or, especially, the social relationship among the speaker and any addressees. Third, that social relationship shapes any effects caused by a rhetorical question. In other words, the social context of the participants and the speech situation determine which functions utterance of a rhetorical question performs and which, if any, function becomes dominant in the specific context. The need to analyze social context emerges not only from Frank's (1990) appreciation for the capacity of rhetorical question to mitigate or to reinforce the assertiveness of propositions expressed in the utterance, but also from the suggestion, unfortunately not further explained, by Brown and Levinson (1978: 228-230) that a rhetorical question is a means of performing a face threatening act (FTA). Ilie (1994) also portrays the function of challenging as dependent on the social balance between the participants.

\section{The Polish Parliament (Sejm)}

As a subtype of political discourse, parliamentary discourse has received less linguistic, especially pragmatic, analysis than it deserves (cf. e.g. Ilie 2006, 2010). An exception is the parliamentary discourse in the House of Commons, especially if regarded from an intercultural perspective. Probably, the greater attention to the House is founded in its long tradition - the longest of all parliaments - and in being the prototype and template for parliaments emerging later. Furthermore, the House of Commons has specific rules, which might strike non-British observers as peculiar, for interaction and speaking in the chamber. In contrast to the House of Commons, where dissent prevails over consensus, in the Polish Sejm the consensus orientation is clearly more dominant.

Discourse in the Sejm has been analyzed in two publications in English (Ornatowski 2010, 2014) and in several in Polish. Still, even within the literature on political discourse, the Polish parliament remains rather a side issue. Monographs by Laskowska (2004) and Majkowska (2012) deserve mention as examples of pragmatic analysis. Laskowska uses speech act theory to reveal the ubiquity of evaluatives in the speeches of Polish deputies. Identifying the full set of subgenres in Polish parliamentary discourse, Majkowska uses discourse analysis to construct a detailed description of parliamentary communication as a whole. She also finds that evaluation predominates, which is according to centered analysis on world views and often expressed in impolite forms designed to persuade potential voters. 
Despite wide variation from one national parliament to the next in specifics, some abstract features of parliamentary discourse are general across all or most parliaments. These features include rules for turn-taking, default forms of verbal address, and institutional preferences for the degree of collectiveness that is permissible or encouraged. The fact that certain formal norms exist in any parliament does not, of course, entail that compliance with the formal norms is full or even prevalent. Compliance depends on political culture that evolves from historical experience. The most recent stage of Poland's political history began with the first non-communist government in 1989 and continues to the present day. Despite the overthrow of communist rule, today's Sejm perpetuates some practices characteristic of and evidently inherited from the socialist era (Ornatowski 2010: 234). Hangovers from the previous regime are evident in reduced interaction between speakers. They are most visible in the absence of immediate answers to spoken questions. During question time, all questioners ask their questions consecutively. Only when the last questioner has finished does a single respondent present a general answer to all the issues raised by the questioners. This procedure naturally allows the respondent to omit or downplay issues that are inconvenient or awkward for the respondent to address. Elsewhere parliamentary question time may be "the most adversarial among parliamentary genres" (Ayala 2001: 159), but the Polish procedure mitigates aggressiveness in question time, which is consequently no more adversarial than other parliamentary subgenres. ${ }^{2}$ Although deprived of the opportunity for verbal aggression in question time, Polish deputies are still able to compensate in other contexts because all items on the Sejm's agenda are discussed according to a uniform procedure. Discussion of each agenda item begins with a presentation by a representative of the commission to which the draft agenda item has previously been referred. The commission representative presents the commission's amended draft of the agenda item in question. A representative of the government speaks next, followed by representatives of each of the various clubs (the name for fractions). Finally, all deputies may pose questions about the amended draft. As in question time, they pose their questions consecutively without receiving answers to each question immediately. Once all the questioners on the initial list of registrants have used their time, the original representatives from the commission and from the government answer

2 The topic of the question time ("informacja bieżaca"), which is obligatory in each debate, is determined by the council of elders. Besides this question time, in every debate took place a more formal question time called "question on current issues" ("pytania w sprawach bieżacych"). In contrast to the genuine question time, here the questions were submitted to the government in writing before. Hereby the degree of spontaneity of orality by both, the emitter and the recipient, is rather low, because they almost always read the questions out in the plenum. 
all questions in bundled form. No questioner may formulate any further requests, remarks, or supplementary questions, even if the representatives of the commission and the government have ignored the original question.

Accordingly, for nearly every agenda item, an admittedly small question time occurs. Every agenda item therefore offers the opportunity for controversy, confined only by the limits of the topic being discussed. I will call this parliamentary subgenre issue specific question time.

During issue specific question time, the Speaker usually allocates time to speak, and each MP receives one to three minutes. How long each MP may speak depends on the time previously allocated to debate on the issue at hand and on the number of MPs desiring to pose questions. The number of questioners indicates the importance of the issue being debated and the opportunity for deputies to gain by asking questions about it. MPs especially benefit during so-called emergency debates that, in the case of the Sejm, concern emergency or conflictual topics. Certain subjects, for example ideological issues, are expected to become controversial because of the strong polarization of Polish politics "between two major blocks" (Ornatowski 2010: 232) that have emerged since the system change in 1989. An emergency topic can be added to the agenda of a scheduled debate for the sake of responding to some current incident or political affair. Formally it is an "Information of the Prime Minister about..." ("Informacja prezesa Rady Ministrów o...") that does not require the deputies to vote or to consider a resolution or law. The concerned member of the government presents the information and answers the questions. These emergency topics draw the public attention, that is noticeably weaker for formal question time in the Sejm than for question time in the House of Commons, not to mention for Polish parliamentary discourse in general.

Finally, Polish parliamentary discourse adheres to regular patterns of address. All speakers must overtly direct their statements and questions to the Speaker (“Mrs Speaker!”/“Pani Marszatek!”). They may optionally also overtly address the chamber, an official such as the Prime Minister ("High Chamber! Mr Premier!”/“Wysoka Izbo! Panie Premierze!”), or the plenum. From a pragmalinguistical perspective, these overt forms of address conceal a variety of covert addressees, as deputies may be speaking to the physically absent public, to the media, to all voters, only to their base electorate, to their club or to their whole party, or the opponents, etc. (cf. Kühn 1995)

The observation that "form is important, but performance is crucial" (Chilton 2004: 108) pertains to all parliamentary discourse, yet question time stands out for offering MPs "the chance to score a political point" (Ayala 2001: 159). In routine debates that draw little public attention, the main perlocutionary goals on the macro-level include eliciting information, gaining consideration for merits of 
alternative courses of action, or seeking action by the government. The macrolevel perlocutionary goal in emergency debates can be described as recruiting voters in future elections. If the deputy's party wins more votes in a future election by participating actively in a debate, the perlocutionary effect is achieved. Resort to rhetorical questions on the micro-level in parliamentary discourse offers one strategy to accomplish the macro-level goal of recruiting voters. For that reason, all examples of rhetorical questions discussed in this paper have been chosen from a single debate that drew extraordinary public attention. ${ }^{3}$

\section{Rhetorical Questions in Parliamentary Discourse}

\subsection{Rhetorical Questions and Verbal Responses}

The implication of classical rhetorics that rhetorical questions preclude answers is oversimplified and obsolete, as the following sample from the Polish Parliament proves:

(1) Proszę państwa, co Platforma Obywatelska potrafi robić? (Poseł Anna Zalewska: Nic.) (Głos z sali: Nic nie robi.) ${ }^{4}$

[Ladies and Gentlemen, what is the Civic Platform [the ruling party] able to do? (MP Anna Zalewska: Nothing) (Interruption from the chamber: They do nothing.)]

(Piotr Polak (Prawo i Sprawiedliwość, 'Law and Justice'), 30 August 2012)

Although this question is unambiguously rhetorical, it draws an immediate answer, and from no fewer than two deputies. They interrupt from the benches with the predictable answer "nothing". Since the speaker's own implication is

\footnotetext{
3 All samples in this paper are taken from a so-called emergency topic about the bankruptcy of the big financial service provider "Amber Gold". As a consequence, many Polish people potential voters - lost their deposits. Illegal activities linked with a pyramid scheme are considered as the main reason for the bankruptcy. Thus, that debate was a proper opportunity for the opposition to take the government into responsibility for failures in the recent past and benefit from it. This is proved by the amount of 175 MPs, who asked questions in time frames of one minute per speaker.

4 In the shorthand reports ("sprawozdania stenograficzne") heckling is tagged by round brackets. If they are able to attribute the heckle to an individual deputy, the stenographers write the heckling down by the name of the heckler. These transcripts are the source for all samples in this paper. The transcripts are fully free accessible on the Sejm's webpage, http://www.sejm.gov.pl/ Sejm7.nsf/stenogramy.xsp (last accessed on 22 November 2015).
} 
also clearly negative, the explicit answers in example 1 verbalize the speaker's implicated answer. Of course verbalization of an answer to a rhetorical question is no new finding, as Ilie has shown based on analyzes of political speeches and courtroom discourse (1994: 84-85). Verbalization may come either from audience members or from the speaker. Indeed, self-answering to rhetorical questions is characteristic of the subgenre of political speeches within political discourse (Ilie 1994: 139). While in example 1, fellow party members of the speaker verbalize the expected negative answer, self-answering by the speaker also occurs in the Sejm:

(2) Jak to się stało? Jak to się dzieje, że urzędy nie zareagowały? Minister finansów mówi: wina wszystkich, tylko nie moja. To jest jego kompetencja? To jest, proszę państwa, pokaz niekompetencji i lekceważenia ważnych spraw państwowych i ważnych spraw ludzkich. Zwykłych spraw ludzkich, niezwykle ważnych.

[How did this happen? What is going on that the state authorities didn't react? The finance minister says: everyone is to blame except myself. Is that his competence? It is, Ladies and Gentlemen, a demonstration of incompetence and of disregard for crucial state policies and for crucial human matters. Of usual human matters, but unusually crucial ones.]

(Andrzej Duda (Prawo i Sprawiedliwość, 'Law and Justice'), 30 August 2012, emphasis mine B.N. $)^{5}$

The speaker shortens and thus simplifies the utterances of the finance minister, although pretending to quote him directly. Proceeding from that face-threatening simplification, the MP asks a rhetorical question concerning the competence of the minister. Of course, always blaming others is semantically not a competence, but the speaker presupposes it. In parliamentary discourse the implicated answer can be dichotomous, depending on the social relationships between the speaker and the addressees. An addressee belonging to the same ideological group as the speaker answers ironically: "Yes, that's his competence." A responder who is an opponent of the speaker, while recognizing the implicated answer, refuses to commit to it. In (2) the speaker gives the answer himself. Contradicting the implicated ironic, positive answer, his answer is negative, treating his own question as non-ironic. By refusing to violate the maxim of quantity by uttering an obvious truth, the speaker mentally reverses his answer from "yes" to "no" and extends the answer with the ideologically loaded "disregard for crucial state policies and for crucial human matters," to deny competence to the minister. The self-answer in (2) is unusual among complements to rhetorical questions in the Sejm. Turn-taking rules during specific issue question time explain the infrequency of self-answered rhetorical questions.

5 In the following examples, underlined words and phrases are my emphases. B.N. 
Issue specific question time in the Polish Sejm is highly productive of rhetorical questions, as it is for oral questions in general. Intent to pose a question is the formal criterion for an MP to become eligible to speak. Naturally, MPs often flout this institutional restriction on the syntax of their utterances. A self-answer to a (rhetorical) question would seem a particular flagrant case of the many breaches of parliamentary decorum that deputies commit anyway. Although the Speaker occasionally calls the deputies to order, no real sanctions are available to enforce the requirement to pose questions. Still the expectation that MPs will pose questions probably decreases the frequency of examples like (2) in the issue specific question time. Self-answers occur more often in the declarations of opinions by the parliamentary clubs, whose representatives are not bound by the requirement to pose questions.

Nonetheless, examples from "issue specific question time" with self-answers, such as (2), are quite complex. Another example, even more subtle in its functioning as a rhetorical question, is (3):

(3) Czy Polska jest zielona wyspa, słynna zieloną wyspą? Okazuje się, że tak. Jest zieloną wyspą dla oszustów.

[Is Poland a green island, a famous green island? Actually, it happens to be one. It's a green island for frauds.]

(Piotr Polak (Prawo i Sprawiedliwość, 'Law and Justice'), 30 August 2012)

In the rhetorical question the speaker alludes to the winged phrase describing Poland as a "green island," familiar from a 2009 speech by then Prime Minister Donald Tusk. Tusk called Poland a "green island" within the European Union to highlight Poland's positive economic growth against the backdrop of global financial crisis. The speaker in example (3) obviously opposes the concept of Poland-as-green-island. The implicated answer would have to be "No, Poland is not a green island". Because his verbal response does not reject this implicated answer to his rhetorical question, the implication that "Poland is not a green island!" holds. The speaker alludes to Tusk's original positive connotation by verbalizing the affirmative answer "Yes, Poland is a green island". But simultaneously the speaker flouts the affirmative answer by replacing the mental proposition "economic growth" with the spoken proposition "frauds".

\subsection{Rhetorical Questions as Statements}

According to Goody "rhetorical question forms minimize the emphasis on the information channel" and they can be considered as the "opposite to the pure information questions” (1978: 30). Considering example 1 once again - “...what is 
the Civic Platform able to do?" - the speaker transfers no information, at least no new information. Among others, Athanasiadou continues Goody's approach by classifying rhetorical questions as one of four question types based on the speaker's intention (1991: 111). ${ }^{6}$ Athanasiadou discerns a main discursive function of rhetorical questions to be holding the attention of the listener by emphasizing a particular argument or message (1991: 119). Example 4 illustrates this discursive function:

(4) Jeśli zniechęcał pan syna do pracy dla pana Plichty i OLT po uzyskaniu informacji z ABW, to czemu nie spowodował pan upublicznienia tych wiadomości i uruchomienia działań właściwych organów dla zabezpieczenia interesów obywateli w tym samym czasie, w którym uznał pan, że kontakt z panem Plichtą zagraża interesom pana syna? Czy nie uważa pan, że takie zaniechanie w wykonaniu premiera jest co najmniej nieetyczne wobec obywateli?

[If you [Mr Prime Minister] discouraged your son from working for Mr Plichta and OLT after getting this information from $A B W$ [internal security agency], why didn't you arrange both the release of this knowledge and the start of activities of the appropriate authorities in order to protect the interests of the citizens, while acknowledging that the contact to $\mathrm{Mr}$ Plichta is threatening the interests of your son? Don't you think that such a renunciation omission committed by the Premier is, at least, unethical towards the citizens?] (Jan Cedzyński (Ruch Palikota, 'Palikot’s Movement'), 30 August 2012)

The interrogative particle " $c z y$ " is the most frequent marker of a yes-no question in Polish. The addresser thus restricts the possible answers to two: either "No, I don't find such behavior unethical" or "Yes, I find such behavior unethical". Obviously, the speaker anticipates the first answer while considering the second to be correct. Even if we take into account the possibility that both answers could be valid, neither answer, nor even the question, presents interesting or new information. Instead the speaker is emphasizing the propositional content. In his view the behavior he describes is naturally unethical. The illocution in (4) is obviously the evaluative assertion that "behaving like that is unethical towards the citizens". At the moment of posing the question it is irrelevant whether the primary addressee, the Prime Minister, shares the questioner's commitment. Although the overt addressee is the Prime Minister, his reaction is irrelevant to any of the utterance's implications or to its mental uptake by the audience.

Rhetorical questions commit the speaker not only to some implicated answer (Ilie 1994: 56) but also to the propositional content of the utterance posed as an

6 The other three modes of questioning are information seeking questions, examination questions, and indirect requests (Athanasiadou 1991: 107-109). The author used "The Corpus of English Conversation” by Quirk \& Svartvik (1980) as source for the rhetorical question. 
interrogative. The questioner conveys this commitment or agreement to the propositional statement of the rhetorical question. In a perfect world from the speaker's perspective, all addressees share his commitments. If they do not share the commitments, an utterance in the form of a rhetorical question convinces them. Example 5 illustrates how both commitment to an implicated answer and commitment to propositional content can differ between speaker and addressees:

(5) Stworzyliście prokuraturę rzekomo niezależną, ale pan prokurator generalny jest tak naprawdę uzależniony od Krajowej Rady Prokuratury. Nie może zrobić nic. Nie może wszcząć postępowania dyscyplinarnego, nie może odwołać prokuratora w Pcimiu Dolnym, jeśli ten jest podejrzany o korupcję, bo musi mieć zgodę Krajowej Rady Prokuratury, a na czele tej Krajowej Rady Prokuratury stoi pana człowiek - pan Zalewski. A więc jaka to niezależność prokuratury?

[You have established an allegedly independent public prosecution procuracy, whereas in reality, the procurator is dependent on the National Procuracy Council. He can't do anything. He can't institute a disciplinary procedure, he can't recall the procurator in Pcim Dolny, when this man is suspected of being corrupt, because he needs the consent of the National Procuracy Council, and at the head of this National Procuracy Council stands your man - Mr Zalewski. So, what kind of public procuracy's independence is this?]

(Arkadiusz Mularczyk (Solidarna Polska, 'United Poland'), 30 August 2012)

The speaker presents an argument affirming the propositional content of the concluding rhetorical question - "the public procuracy is not independent" - by characterizing the contemporary condition of the public prosecution in Poland. The speaker's commitment to his implicated answer is easy to recognize: he disapproves the situation that he describes. A listener belonging to the speaker's opponents would share the commitment to the speaker's implicated answer. Nevertheless, such a listener would reject the underlying proposition as untruthful. Consequently, he would (at least mentally) formulate an answer to the rhetorical question which stands in contrast to the answer implicated by the speaker.

Utterance of the proposition in the rhetorical question is face threatening, since the government upheld by the speaker's opponents will lose credibility if the speaker's various audiences, direct or indirect, agree that the public procuracy lacks independence. Each group operating in parliamentary discourse recognizes the commitments and agreements of all other groups. Each group even recognizes any FTA, but the requirement to ask questions deprives every group, except the speaker, of any institutionalized opportunity to reject an FTA voiced as a rhetorical question or to explain the matter from its own perspective. In summary, it can be said that the perception of rhetorical questions by all actors within the parliamentary discourse can coincide in a shared recognition of the implicated answer to which the speaker commits. At the same time, the various actors' perceptions can diverge with respect to whether they agree or disagree with the 
conveyed proposition to which the speaker commits. Passage 6 offers a second example where commitment converges but agreement diverges.

(6) Pani Marszałek! Wysoka Izbo! Panie Premierze! Ile musi jeszcze paść pytań z tej mównicy, żeby pan właściwie zakończył sprawę?

[Ms Speaker! High Chamber! Mr Premier! How many questions from this desk are still needed to complete that case appropriately?]

(Jerzy Borkowski (Ruch Palikota, 'Palikot’s Movement'), 30 August 2012)

To comply with the requirement that every intervention consists of a question, in (6) the speaker exploits the norm that every contribution will begin with an institutionalized greeting by uttering three greetings; he then immediately launches into a rhetorical question. The triply geminated greeting serves to underline how unambiguous the proposition is, that the rhetorical question conveys: "No need for additional questions from this desk." Members would certainly agree that additional questions from any desk in the chamber do not end any debate on a controversial issue, such as the one that provides the context for (6). Hidden behind MP Borkowski's rhetorical question is another assertion: "Many questions being posed are being asked only in order to repeat arguments concerning issues that have already been fully stated." In contrast to the shared commitment concerning what answer is implicated (that no further questions are needed), agreement with that answer diverges: one group would reject any connection between the number of questions and the sufficiency of debate on the issue. The other group, to which the speaker belongs, draws a link between relentless raising of questions and the implicit unwillingness of the government to act on the issue.

In parliamentary discourse, as in political discourse in general, the acceptance of the speaker's commitment most often depends upon the political affiliation. However, even with differing values and thus with differing shared commitments, the opponent recognizes the speaker's desired response and his desired commitments to the response and the proposition. The speaker knows this setting and does not cherish the illusion that his counterparts can be persuaded. Since persuasive speech cannot be productively addressed toward the other MPs who compose the physically present audience, the physically absent potential electorate composes one set of addressees of rhetorical questions, as also of other verbal strategies. The MP may use rhetorical questions to reinforce the bond to his base electorate or to recruit new voters into the base electorate. Reinforcing the boundary dividing the MP from both present and absent political opponents while bonding with fellow members of the MP's own party, both present in parliament and absent in the electorate, are macro-level functions of all parliamentary discourse (Chilton 2004: 109). These macro-level goals can be realized by rhetorical questions on the micro-level. 


\subsection{Rhetorical questions in question sequences}

As Ilie (1994) has shown, in political speeches rhetorical questions seem to be so dear to politicians that they often occur in sequences. Sequences of rhetorical questions or rhetorical questions mixed with other question types occur frequently in the Sejm, too. When intervening during issue specific question time, the MPs utter questions in either connected or disconnected sequences. It is not unusual to find such sequences in a question-related parliamentary genre. However, pure sequences consisting only of rhetorical questions are rare; usually the MPs mix or alternate different question types. For sake of simplicity, I confine myself here to a dichotomy distinguishing rhetorical from non-rhetorical questions.

(7) Pytam zatem pana premiera, wielkiego admiratora wolności: Co robi polski rząd, aby uwolnić obywateli od przymusowego haraczu płaconego do gigantycznej piramidy finansowej, jaką są otwarte fundusze emerytalne? Co zrobi polski rząd, gdy okaże się, że miliony obywateli zostaną okradzione z emerytur przez OFE i grupy interesów z nimi powiązane? (Dzwonek) Wreszcie chciałabym zapytać: Kto ponosi odpowiedzialność za te wszystkie, przedstawione tak skrupulatnie, naruszenia prawa?

[Now I ask the Prime Minister, that great admirer of liberty: What is the Polish government doing to liberate citizens from the protection racket imposed on them by that gigantic financial pyramid scheme, the open pension funds (OFE)? What will the Polish government do when it turns out that OFE and stakeholders connected with these funds have stolen the pensions from millions of citizens? (bell rings) At last, I would like to ask: Who bears the responsibility for all these violations of law in the guise of scrupulous compliance?]

(Józefa Hrynkiewicz (Prawo i Sprawiedliwość, 'Law and Justice’), 30 August 2012))

By opening example 7 with the ironic characterization of the prime minister as "that great admirer of liberty," the speaker hints that his meaning will not be solely literal. The ironical marker reduces the risk of inaccurate decoding of the following two rhetorical questions. The mutually reinforcing unambiguity of the two nearly identical rhetorical questions can cognitively trigger a mental transfer of the unambiguity to the following third question, which is non-rhetorical. It can be either an "elicit:inform" utterance (Tsui 1992: 102), seeking the name of a responsible person, or a request for action ${ }^{7}$ seeking punishment of the responsible person. The implicated answer is obvious from the presupposition - there must be someone responsible affiliated to the Prime Minister or his government's

7 The MPs benefit more from asking questions to press the government for action than to obtain information (Adonis 1993). 
environment - which the sequence of questions renders even less disputable than it would be anyway.

(8) Pani Marszałek! Wysoka Izbo! Panie Premierze! Nie mam zdolności profetycznych, ale 3 lata temu, kiedy zmieniano ustawę o prokuraturze, kiedy wy zmienialiście tę ustawę o prokuraturze, opozycja mówiła, że działania prokuratora będą działaniami, delikatnie rzecz ujmując, budzącymi wątpliwość. Dlaczego? Dlatego że prokuratura tak naprawdę nie jest w pełni niezależna, jak pan chciał tutaj wszystkim posłom przedstawić. Jest przede wszystkim zależna od pana. Pan uniezależnił prokuraturę od kontroli Sejmu, a tym samym od kontroli wyborców. Natomiast uzależnił ją pan, jak nigdy dotąd w jej historii, od siebie. Prokurator generalny jest zależny od pana przede wszystkim od strony finansowej, jest także zależny instytucjonalnie. Czy pan wie, jak wygląda zwierzchni nadzór służbowy? Czy pan wie, że w ramach zwierzchniego nadzoru służbowego można bardzo łatwo wpływać na działania prokuratora referenta? (Dzwonek) Czy pan wie o tym, że prokurator generalny ma niewielkie możliwości karania tych prokuratorów, którzy źle działają?

[Mrs Speaker! High Chamber! Mr Premier! I have no clairvoyant abilities, but three years ago, when the procuracy law was being changed, when you [plural, B.N.] were changing the procuracy law, the opposition mentioned that the public procuracy's activities - to put it mildly - would raise doubts. Why? Because the public procuracy is not at all as independent as you [Mr Prime Minister, B. N.] wanted to show all the deputies here. Primarily, it is dependent on you. You have made the procuracy independent of the Sejm's control and of the electorate's control, as well. On the other hand, you have made the procuracy dependent on you, as it has never been in history until now. The procuratorgeneral is primarily dependent on you financially, as well as institutionally. Do you know what the supreme service inspectorate looks like? Do you know that for the supreme service inspectorate it's very easy to exert influence on the deputy procurators? Do you know that the procurator-general has only restricted powers to sanction the procurators who perform poorly?]

(Marzena Dorota Wróbel (Solidarna Polska, 'United Poland'), 30 August 2012)

By opening with a detailed description of the public procuracy's current condition, the MP's uttering (see example 8) constructs herself as competent to enter the debate. By then requesting the knowledge of the addressee with three parallel yes-no questions, she implicates that the addressee does not even know a single one of the answers. This move exploits the Sejm's norm that oral questions during debate purport being "real" interrogative acts expecting authentic answers from a knowledgeable interlocutor. The norm in the Sejm stands in sharp contrast to questions embedded in political speeches, or in any other relatively monologic subgenres of political discourse, such as government declarations. At the same time, a full spatiotemporal analysis would consider "participant positioning in space and time" (Ilie 2006: 192). Such an analysis calls attention to the presence of incomplete adjacency pairs. All questions posed at any minute may draw answers delayed in time, whether within ten minutes or within two hours. The 
temporal delay depends on how many deputies ask questions before the presenters resume the floor to respond to all the questions at once.

The MPs do not have to justify themselves for implicating and insinuating statements camouflaged as questions. At worst, they may encounter immediate heckling from the benches. The deputies are fully aware that the Speaker may not rebuke them for breaking the rules of question time by making assertions as long as they frame their assertions in interrogative syntax as rhetorical questions.

I claim that the time lag between the questions and their verbal responses further motivates the speakers to convey statements, commitments, and evaluations. The parallel yes-no question sequence in (8) raises a meta-question whether the speaker would be satisfied by a combined answer such as: "The answer to Ms Deputy Dorota Wróbel is three times 'yes"' - especially if this combined answer occurred three hours later, when everyone had forgotten her original questions. The speaker of example 8 gains mainly by posing assertions that are polar, evaluative and face threatening. She (in this case) would be best off if the answerer merely repeated her face-threatening propositions stated in her questions. Naturally, an answerer does not do that.

Instead of posing questions in sequences, speakers sometimes coordinate them by conjunctions:

(9) Powstaje pytanie, dlaczego Urząd Lotnictwa Cywilnego nie zweryfikował cen dumpingowych stosowanych przez OLT i ich wpływu na rynek przewozów lotniczych? Przecież dotyczyło to spółek Skarbu Państwa, wszystkich wyjazdów turystycznych. Gdzie był minister transportu i co w tej sprawie zrobił?

[The question arises, why the Civil Aviation Authority didn't verify the dumping prices applied by OLT and their influence on the aviation market? Well, this concerned companies of the treasury and all tourist travel. Where has the transport minister been and what has he done in this matter?]

(Grzegorz Tobiszowski (Prawo i Sprawiedliwość, 'Law and Justice'), 30 August 2012)

The interrogative acts might have been segregated: "Where has the transport minister been?" "What has the transport minister done in this matter?" The implicated answer to the first question is obvious and would be approximately "nowhere" or "not where he should be". If posed separately, the second question could be construed as information-eliciting. By combining these two questions into one with a coordinating conjunction, as in (9), the speaker transports the implicated negative answer to the rhetorical question across the conjunction to the information question, the answer to which is otherwise not as self-evident as the answer to the preceding rhetorical question. 


\section{Conclusion}

The frequency of rhetorical questions in the Sejm depends on the parliamentary subgenre. Parliamentary debates display various degrees of spontaneity and conflict potential. The source of rhetorical questions in this paper was chosen in accordance with these criteria. All questions were taken from the parliamentary subgenre issue specific question time, which is an integral component of nearly all debated agenda items in the Polish parliament. Furthermore, the chosen debate issue was an emergency topic enjoying high public attention. I assumed that the deputies are especially motivated to benefit from their appearances in this debate. In this dual context, the frequency of rhetorical and other noninformation-eliciting questions proved to be high. This finding is not surprising in a subgenre strictly confined to posing questions. Issue specific question time entails three major characteristics. First, nearly every MP who desires time to speak must use interrogative syntax to convey his or her messages and subtexts. Second, other than the requirement to speak for no more than one to three minutes, the constraint to pose one or more questions is the only restriction on what an MP may say. Third, dialogic interaction is limited because no question receives an answer until all participants have finished asking their questions.

This is a pattern that presents the responders with the option to ignore any given question because the questioners have no opportunity for supplementary questions or intervention from the floor other than heckling. Consequently the analysis confronts the problem of incomplete adjacency pairs separated by the time lag between any given question and its answer, if there is one. Functionrelated restrictions and rules for turn taking therefore reinforce the incentives for MPs to use issue-related question time for the purpose of delivering brief, concise messages. Rhetorical questions achieve this purpose.

A rhetorical questions remains superficially a "question". Therefore, rhetorical questions are proper speech devices in accordance with their richness of various functions. Due to the multifunctional character of rhetorical questions, different functions can be fulfilled simultaneously. Thus, rhetorical questions are a legitimized and very suitable medium to be used in short question-related contributions within the parliamentary discourse.

As has been shown, three discursive aspects of rhetorical questions are characteristic in Polish parliamentary discourse. First, verbalized responses to rhetorical questions occur rarely. The MPs most often waive verbalized selfanswering because of the constraint to pose questions. Self-answering would delegitimize the right to speak in Issue specific question time. In some cases, fellow party members verbalize the speakers' implicated answers by interruptions from the floor. In other cases, the speakers complicate their verbal answers by 
adding an ironic or complex answer that literally does not fit with the implicated answer. However, the implicated answer still holds true.

Second, treating rhetorical questions as statements is the most important feature of Polish parliamentary discourse. The speaker's commitments to his or her implicated answer and to the propositional statement in question have to be considered as sophisticated. All addressees, be they physically present or absent, fellow party members or representatives of a rival party, recognize the implicated answers and the speakers' commitments. Poland's strong political polarization can even lead to the opponent's sharing of the commitment to the answer while rejecting the underlying assertions.

Third, deputies use rhetorical questions in question sequences in various ways. Rhetorical questions appear in pure sequences with other rhetorical questions or in mixed sequences, both with standard questions or with other kinds of non-standard questions. These sequences may be continuously connected or may be disconnected, interrupted by non-interrogative utterances. Connected sequences mixed with other questions seem to be especially persuasive. Connection of sequences of questions can effect a cognitive transfer of the implicated answer, as well as the unambiguity of the answer, from an introductory rhetorical question to its otherwise non-rhetorical segue. Thus an answer to a non-rhetorical question can come to seem as obvious as answers to rhetorical questions do.

\section{References}

Adonis, Andrew. 1993. Parliament Today, 2nd edn. Manchester: Manchester University Press. Athanasiadou, Angeliki. 1991. The Discourse Function Of Questions. In Pragmatics: quarterly publication of the International Pragmatics Association (IPrA) 1. 107-122.

Brown, Penelope and Stephen C. Levinson. 1978. Universals in language usage: politeness phenomena. In Esther Goody (ed.), Questions and Politeness: Strategies in Social Interaction, 106-229. Cambridge: Cambridge University Press.

Chilton, Paul. 2004. Analysing political discourse. Theory and practice. London: Routledge.

Frank, Jane. 1990. You call that a rhetorical question? Forms and functions of RQs in conversation. In Journal of Pragmatics 14. 723-738.

Goody, Esther. 1978. Towards a theory of questions. Questions and Politeness. Strategies in Social Interaction. In Esther Goody (ed.), Questions and Politeness: Strategies in Social Interaction, 17-43. Cambridge: Cambridge University Press.

Ilie, Cornelia. 1994. What Else Can I Tell You? A Pragmatic Study of English Rhetorical Questions as Discursive and Argumentative Acts. Stockholm: Almqvist \& Wiksell International.

Ilie, Cornelia. 1995. The validity of rhetorical questions as arguments in the courtroom. In Frans Hendrik van Eemeren, Robert Grootendorst, J. Anthony Blair \& Charles A. Willard (eds.), Special Fields and Cases. Proceedings of the Third International Conference on Argumentation, 73-88. Amsterdam: SICSAT. 
Ilie, Cornelia. 1999. Question-response argumentation in talk shows. In Journal of Pragmatics 31. 975-999.

Ilie, Cornelia. 2006. Parliamentary Discourses. In Keith Brown (ed.), Encyclopedia of Language and Linguistics, 2nd edn, vol. 9, 188-196. Oxford: Elsevier.

Ilie, Cornelia. 2010. Identity co-construction in parliamentary discourse practices. In Cornelia Ilie (ed.), European Parliaments under Scrutiny: Discourse strategies and interaction practices, 57-78. Amsterdam: John Benjamins.

Kühn, Peter. 1995. Mehrfachadressierung. Untersuchungen zur adressatenspezifischen Polyvalenz sprachlichen Handelns. Tübingen: Niemeyer.

Lachenicht, Lance G. 1980. Aggravating language. A study of abusive and insulting language. In International Journal of Human Communication 13(4). 607-687.

Laskowska, Elżbieta. 2004. Dyskurs parlamentarny w ujęciu komunikacyjnym. Bydgoszcz: Wydawnictwo Akademii Bydgoskiej.

Majkowska, Aneta. 2012. Debata sejmowa jako gatunek wypowiedzi. Opole: Wydawnictwo WCM.

Pérez de Ayala, Soledad. 2001. FTAs and Erskine May: Conflicting needs? - Politeness in Question Time. In Journal of Pragmatics 33.143-169.

Ornatowski, Cezar M. 2010. Polish Parliament after 1989. In Cornelia Ilie (ed.), European Parliaments under Scrutiny, 223-264. Amsterdam/Philadelphia: John Benjamins.

Ornatowski, Cezar M. 2014. Learning to differ: Transforming parliament through argument and debate in Poland post-1989. In Hilde Van Belle, Kris Rutten, Paul Gillaerts, Dorien Van De Mieroop \& Baldwin Van Gorp (eds.), Let's talk politics: New essays on deliberative rhetoric, 185-204. Amsterdam/Philadelphia: John Benjamins.

Schaffer, Deborah. 2005. Can Rhetorical Questions Function as Retorts? Is the Pope Catholic? In Journal of Pragmatics 37. 433-460.

Schmidt-Radefeldt. Jürgen. 1977. On so-called “rhetorical” Questions. In Journal of Pragmatics 1. 375-392.

Tsui, Amy. 1992. A Functional Description of Questions. In Malcolm Coulthard (ed.), Advances in Spoken Discourse Analysis, 89-110. London: Routledge. 